\title{
The Strategy of Waqf Influencing through International Center of Awqaf Studies Indonesia
}

\author{
${ }^{1}$ AHMAD FANANI, ${ }^{2}$ NORHAZLIN MUHAMMAD \\ 1,2 Sultan Omar 'Ali Saefuddien Centre for Islamic Studies, Universiti Brunei Darussalam, \\ Jalan Tungku Link BE1410, Brunei Darussalam \\ correspondence author: fannan677@gmail.com
}

\begin{abstract}
Waqf has an important role in improving social life, economy, welfare, education, and creating zero hunger as stated in the Sustainable Development Goals in 2015. However, many Muslims still do not know the definition and function of waqf. Even though Indonesia is known as Muslim Country Population (WCP), it still has constraints in the economy and welfare of its population. University of Darussalam (UNIDA) Gontor in collaboration with the Central Bank of Indonesia establish International Center of Awqaf Studies (ICAST) as a place of creating successor on waqf specialization through various programs that expected to enhance waqf understanding and formulate the experimental cases of waqf in Gontor Indonesia that existed since 1958 till now. This research aims to disseminate waqf to the people of Indonesia until waqf accepted and implemented easily. This research uses descriptive qualitative method with a case study in the ICAST. The conclusion of this research is ICAST disseminating waqf understanding to many levels of society through several programs, such as the establishment of master in waqf economics, research and publications, nazir waqf certification, seminars, and workshops by using three approaching techniques of the head, heart, and hand tactics.
\end{abstract}

Keywords: ICAST, influencing, waqf understanding

\section{Introduction}

Waqf is one of the instruments in Islamic economics that has the potential to improve people's welfare. Besides having a function as a means of worship to Allah, waqf also has a social function. It can provide an enormous advantage for the people if they can be managed optimally and productively.

Indonesia with a majority Muslim population and having large area holds a huge potential for waqf. However, this potential has not been managed and utilized optimally in a productive direction. Based on data obtained from Islamic Economic Forum for Indonesian Development, Indonesian Waqf Board explained that Indonesia has 435,944 hectares where 287,160 ha of asset is certified and 148,447 ha is uncertified ('Potensi dan Kontribusi Wakaf di Indonesia - ISEFID', n.d.). Data on waqf land throughout Indonesia can be seen in the following Table 1 (Hendra, 2019).

Table 1

Data of All Indonesian Waqf Land in 2016

\begin{tabular}{lr}
\hline \multicolumn{1}{c}{ Province } & \multicolumn{1}{c}{ Area $\mathbf{~ m}^{\mathbf{2}}$} \\
\hline $\begin{array}{l}\text { N a n g g ro e A c e h } \\
\text { Darussalam }\end{array}$ & $767.869 .011,58$ \\
North Sumatera & $36.035 .460,00$ \\
West Sumatera & $212.212 .380,00$ \\
South Sumatera & $380.456 .227,29$ \\
Riau & $1.183 .976 .528,00$ \\
Jambi & $13.516 .703,00$ \\
Bengkulu & $7.122 .171,22$ \\
Lampung & $22.990 .814,00$ \\
Bangka Belitung & $3.243 .060,00$ \\
Kepulauan Riau & $1.066 .799,00$ \\
DKI Jakarta & $3.013 .640,00$ \\
D.I. Yogyakarta & $2.933 .943,00$ \\
West Java & $116.662 .017,81$ \\
Center Java & $163.169 .706,97$
\end{tabular}

Received: 2020-03-28, Revised: 2020-05-05, Accepted: 2020-06-03. 


\begin{tabular}{lr} 
East Java & $58.239 .272,20$ \\
Banten & $39.322 .270,00$ \\
Bali & $13.990 .000,00$ \\
West Kalimantan & $27.544 .360,00$ \\
Center Kalimantan & $5.778 .500,00$ \\
South Kalimantan & $58.239 .272,20$ \\
East Kalimantan & $13.984 .104,00$ \\
North Sulawesi & $1.905 .272,70$ \\
Southeast Sulawesi & $5.225 .958,00$ \\
Center Sulawesi & $165.042 .816,23$ \\
South Sulawesi & $1.029 .030 .278,00$ \\
West Sulawesi & $3.251 .700,00$ \\
Papua & $694.466,00$ \\
West Papua & $591.117,00$ \\
Nusa Tenggara Timur & $5.311 .787,00$ \\
Nusa Tenggara Barat & $25.816 .325,00$ \\
Maluku & $5.006 .359,00$ \\
North Maluku & $30.223 .191,00$ \\
Gorontalo & $1.663 .350,00$ \\
\hline & $\mathbf{4 5 9 . 4 4 3 . 1 7 0 , 0 0}$
\end{tabular}

Source: Directorate of Waqf Empowerment of the Ministry of Religion of the Republic of Indonesia dated March 2016.

However, based on statistical publications relating to the Key Socio-Economic Statistics issued by the Islamic Development Bank (IDB) in 2015, the socio-economic conditions of Islamic countries in the Organization of Islamic Cooperation (OIC) are still far different and quite alarming when compared to other developed countries (Syariah \& Airlangga, 2016). In the case of Indonesia, it has 25.14 million people who live in the poor category ('3412-1565077565-190723_IPP_TingkatKemiskinan-di-Indonesia-Menurun_OP2', n.d.).

The problems above happen because Nazhir (waqf manager) do not understand the essence, definition, legalities, product, technique, and investment of waqf assets. It happens because almost $75 \%$ of Nazhir have no competence in the field of waqf as seen from the scientific or business fields chosen to develop the waqf (Ekonomi \& Iqtishodia, 2018).

Whereas, waqf have a huge function in the economic development and welfare since it commenced at the time of the Prophet Muhammad. Therefore, it is necessary to have a special institution that focuses on spreading waqf ideology, ways of developing productive waqf, waqf-based business concepts to nazhir waqf. The International Center for Awqaf
Studies (ICAST), University of Darussalam Gontor do some strategies to influence waqf understanding to nazhir through the head, hand, and heart tactics with the aim to disseminate this definition or ideology well.

Based on the description above, the purpose of this article is to explain the ways of waqf influencing through ICAST which is established in collaboration with Indonesian Central Bank, function as a center to disseminate a waqf as understanding to all of Nazhir and Muslim people in general.

\section{Research Methodology}

Type of research. Firstly, the type of this research is a qualitative descriptive method, which is a research method that produces descriptive data in the form of written or oral words from people and observed behavior (Utsman, 2014). The qualitative research method is also called the naturalistic research method because the research is conducted in natural conditions. This method is used to get the exact value of the existing data (Sugiyono, 2014). Secondly, library research exploring various references, law books, Acts/regulations, and websites. Data collection tool. Data collection for this research is done through the normative method, which is data taken from essays, books, scientific articles, or documentations (Arikunto, 1998), and also actions as tactics related to disseminating waqf understanding that can influence people through ICAST Indonesia.

Documentation method is collecting data through written documents, especially in the form of archives, books about opinion, theory, creedal, law, and others related to the problem of investigation (Hadi, 1981). Method of data analysis. Descriptive analysis is a method used to objectively describe the importance of influencing people about waqf knowledge.

An inductive approach is concerned with generating a new theory emerging from the data and it has the aim to produce a new theory based on the data (Gabriel, n.d.). Data. Materials sources in this study include primary materials and secondary materials (Pena, n.d.). The explanation is as follows:

Primary materials are materials from libraries such as literature, journals, and other books relating to influencing people about waqf knowledge through International Center for 
Awqaf Studies (ICAST). Secondary materials are materials in the form of books about acts and regulations, Islamic jurisprudence, Islamic economics, Islamic management, and Islamic marketing. Secondary materials can also in the form of enhancement materials for developing competency of people and nazhir about waqf knowledge.

Model Development. Nowadays, the third sector of the economy, which are Zakat, Infaq, Sedekah, and Waqf or known as Islamic social finance, have a great function to develop Islamic civilization. Because of that important function, especially of waqf, Islamic higher education should influence nazhir and Muslim people about waqf knowledge and understanding. Through International Center for Awqaf Studies, the University of Darussalam Gontor increases the competency of nazhir on waqf knowledge/understanding, how to manage waqf properties, and enhancing waqf assets rapidly.

\section{Results and Discussion}

Influence is defined as "a force one person (the agent) exerts on someone else (the target) to induce a change in the target, including changes in behaviours, opinion, attitudes, goals, needs and values" and "the ability to affect the behavior of others in a particular direction" (Hall \& Barrett, 2007).

Other definitions are "about one person making other people think about or do things the way they think or do, to achieve their goals" (Alhamuddin, 2018;). "Convincing others to do or believe something by using certain skills or information to achieve this" (Yiset). "For me, it is the skill to change other people's attitudes, thoughts or behaviours" (Ana Maria) (Fisher \& Santana Gonzalez, 2013).

There are three influencing tactics: the Head, the Heart, and the Hands. Firstly is Logical influencing tactics (the Head) that address people in a rational or intellectual way, arguments and information such as facts and figures brought forward in the best interest of the organization, the team, or the person. Secondly is Emotional influencing tactics (the Heart) that connect the communication or decision with a person's feelings of well-being or a sense of belonging. The leader appeals for attitudes, values, a common purpose, ideals, and beliefs through inspiration or enthusiasm. Thirdly is Cooperative influencing tactics (the Hands) which involve seeking advice and offering assistance. The leader reinforces the connection that he or she has with others, collaborating to accomplish a mutually important goal by extending hands to others (Dellaert \& Davydov, 2017).

\section{Waqf Understanding}

Waqf (pl. awqaf), which literally means forbidding movement, transport, or exchange is a dedicated property usufruct of which to be used for some charitable ends for the duration of the property's existence. The object of waqf is divided into two: private objects (heirs; family or typical; private or posterity) where waqf allows the name of beneficiaries (including the founder) and their descendants to get income until the line of inheritance breaks and the waqf becomes public; and public objects (khayri; pious; or $a^{\prime} m$ ) where waqf is created to serve the interests of society, e.g., awqaf for mosques, schools, scientific research, the needy persons, travelers, etc. Public awqaf may also be established with state funds (America et al., 2010).

Waqf, in Arabic language, means hold, confinement, or prohibition. The word Waqf is used in Islam in the meaning of holding certain property and preserving it for the confined benefit of certain philanthropy and prohibiting any use or disposition of it outside that specific objective. Waqf is called Habs (pl. Ahbas) in North and West Africa. This definition accords with the perpetuity to Waqf, i.e. it applies to non-perishable property whose benefit can be extracted without consuming their property itself. Therefore, Waqf widely rates to land and buildings. However, there are Waqf of books, agricultural machinery, cattle, shares and stocks, and cash money (Kahf, 2016).

Form Shariah point of view, Waqf may be defined as holding a Maal (an asset) and preventing its consumption for the purpose of repeatedly extracting its usufruct for the benefit of an objective representing righteousness/philanthropy. Hence, waqf is a continuously usufruct-giving asset as long as its principal is preserved. Preservation of principal may result from its own nature as inland or based on arrangements and conditions prescribed by the waqf founder (Kahf, 1998).

\section{Nazhir waqf}

In order to develop waqf assets, the waqf institution would have a nazhir of waqf to manage and enhance waqf properties, even this didn't mention in four pillars of waqf. 
Nazhir is one of the elements that must be existed and being fulfilled in the implementation of waqf. The existence of nazhir is also one of the uniqueness in Islamic philanthropy fund management, namely Zakat. Nazhir plays a role to manage and empower the object of waqf so that the existence of the waqf object can provide and bring sustainable benefits for the general public (ummah) (Yumarni, Suhartini, \& Mulyadi, 2019).

Nadzir waqf/endowment according to Government Regulation number 28 of 1977 is categorized into two groups, namely individual nadzir and institutionalized nadzir. Individual nadzir needs to adhere to the following requirements: a citizen of the Republic of Indonesia, a Muslim, an adult, be sound of mind, not under an amnesty, resident in an area where the endowment is located. For an institutionalized nadzir, the requirements are as follows: a legal Indonesian firm and located in Indonesia, a representative in a district where the plot of land (waqf) is located, every nadzir endowment is obliged to register to the Office of Religious Affairs to be legalized. The number of nadzir endowment in every district is determined by the Minister of Religious Affairs (Purwanto, 2004).

Obligations and rights of nadzir is regulated in article $220 \mathrm{CIL}$ and section 7 of PP No.28/1977, as follows: Nadzir is obliged to arrange and be responsible of the waqf property and the execution of waqf procedure on the basis of its objectives. As regulated by the Minister of Religious Affairs, Nadzir is obliged to make a regular report to the local head Office of Religious Affairs (Kepala Kantor Urusan Agama) and a copy to the local District Council of Ulama (Majelis Ulama Kecamatan) and the local Head of District (Camat), regarding all of his responsibilities as indicated in section 16, (1) The procedures of writing the report as mentioned in section; (2) is executed according to the regulations of the Ministry of Religious Affairs (Purwanto, 2004).

\section{Discussion}

\section{International Center for Awqaf Studies (ICAST) Indonesia:}

Waqf plays beyond its ritual form; waqf serves as a driving force to prosperity (falah) in both material and spiritual aspects, for both donator (waqif) and a beneficiary (mauquf alaih) (AlQuran, AnNahl: 97 and Quraish: 14).
One major challenge faced by waqf today is the inability of its trustees (nadzir) to preserve and grow waqf assets. As a result, some waqf assets remain dormant and, in some worst case, deteriorate. Thus, to bring waqf to its optimum potential, from passive asset to productive one, in Indonesia and other Muslim countries, UNIDA Gontor incorporation with Indonesian Central Bank initiated ICAST, International Center for Awqaf Studies. The Center aims to create professional waqf trustees who have entrepreneurship spirit and able to integrate spiritual and moral values by a systematic, rational, and methodological way of thinking (ICAST, 2018).

Another reason from this center is making cadre or successor of waqf who knows the responsibilities as nazhir waqf. This reason has the same lining with Five Long Terms of Pondok Modern Darussalam Gontor or known as Panca Jangka: there are education and teaching, infrastructure, and building, khizanatullah (treasure), making cadres, and family welfare. The meaning of making cadre is a plan to make sure the sustainability and development of Gontor as an Educational Institution by designing the educational and teaching system based on the five spirits or Panca Jiwa (sincerity, simplicity, self-reliance, Islamic brotherhood, and freedom) who can continue and maintain the system of pondok. Basically, all students and teachers are cadres, but in the context of making cadres, there are cadres who register to Pondok to become its cadres, and then sign the agreement to have the right to live Pondok. Here, at Gontor, the Waqf is not only in terms of land, buildings, money, etc. but the Waqf is also in term of human (Umam, 2014).

Collaboration between UNIDA Gontor and Indonesian Central Bank in initiating ICAST is divided into several agendas, especially waqf understanding enhancement. The programs are a development of waqf curriculum and education through Master in Waqf Economics, Research and Publication, Nazhir Waqf Certification, Seminar and Workshop ('Kerjasama Bank Indonesia dan Universitas Darussalam Gontor - Bank Sentral Republik Indonesia', n.d.).

In another side, Yayasan Pemeliharaan dan Perluasan Wakaf Pondok Modern (YPPWPM) as one of five high institutions in Pondok Modern Darussalam Gontor would like to contribute in this movement with various programs which the main goal is enhancing nazhir waqf potency in investment, writing 
the report, taking and calculating the risk management of wealth, running a waqf-based business with supervising and controlling from those institutions.

International Center for Awqaf Studies (ICAST), in influencing of waqf understanding, has various programs which are divided into four: Master in Waqf Economy, Research and Publication, Nazhir Waqf Certification, Seminar and Workshop. The following is the explanation of each program of ICAST.

\section{Master in Waqf Economics}

In disseminating the understanding of waqf, higher education institutions must hold many innovative programs such as the strengthening of waqf literacy program for the younger generation, especially students as educated generation elites and future national leaders, such "waqf goes to campus", study programs, research, and so on ('Wakaf Kekinian Masuk Kurikulum Pendidikan Makassarinside.com', n.d.).

The program for two year fulltime is designed to provide rigorous training on waqf studies, giving students the opportunity to develop advanced, analytical, and technical skills which are highly sought after by waqf institution. ICAST offers Master by coursework and by research program, so students can do their research program by project or thesis mode.

The programs are Coursework \& Intensive Literary Research, Internship \& Field Research (Methodology), and each program consists of sixteen taught modules - twelve cores and four electives - and culminates in a waqf research project or thesis shown below (U. of D. Gontor, 2018)

\section{Research and Publication}

Improving the quality of human resources and understanding of the community in the field of waqf must be encouraged. This is because the quality of graduates of Islamic Economics \& finance programs is not optimal when viewed from the accreditation of study programs in 2017; Accreditation A was around $8 \%$, B was $48 \%$, C was $38 \%$, and Expiration was around $6 \%$. Meanwhile, in 2016 , the financial literacy and inclusion index was very small, such as the Islamic financial literacy index which was $8.10 \%$, and the Islamic financial inclusion index of $11.10 \%$; those are far compared to the conventional financial literacy index of around $29.50 \%$ and the conventional financial inclusion index of $65.60 \%$. Therefore, increasing sharia economic literacy through research \& assessment, institutional, education \& socialization needs to be developed (Anwar Bashori, Ekonomi, \& Syariah, 2018).

The problem above makes ICAST Research Centre focus on waqf study with various sectors (Islamic and conventional banking, non-banking financial institution, capital market, pesantren, etc.). There is much Islamic economics research in the areas related to waqf, but not limited to Historical \& Best Practice of Waqf, Good Nadzir Governance (Licensing Criteria), Risk Management of Waqf, Performance Measurement of Waqf Institution, Performance Audit Model for Nadzir, Waqf Fund for Poverty Alleviation and Waqf for Sustainable Economic Development. The research themes are set to respond to the need of Sustainable Islamic Economics Development Goals (SIEDG's) (U. of D. Gontor, 2018).

Table 2

The Module of Study

\begin{tabular}{ll}
\hline \multicolumn{1}{c}{ Core Module } & \multicolumn{1}{c}{ Elective Module } \\
\hline Islamic Worldview & Waqf Seminar \\
History of Waqf Civilisation & Islamic Capital Market \\
Fiqh of Waqf & Advanced Financial Theory \\
Legal Aspects of Waqf & Applied Econometrics \\
Research Methodology & \\
Principles of Financial Analysis & \\
Islamic Wealth Management & \\
Islamic Social Finance & \\
Waqf Asset Management & \\
Waqf Financial Planning & \\
Waqf Risk Management & \\
Waqf Accounting & \\
Practicum/Internship & \\
\hline
\end{tabular}




\section{Nazhir Waqf Certification}

Nazhir Waqf Certification (NWC) is a prestigious and highly respected waqf certification institution in the waqf area. It was established as a professional institution to train future prominent Nazhir waqf in the waqf industry. As vocational education which has a rigorous education, extensive waqf industry experiences, and sustainable education, NWC practitioners will be known as tough and professional Nazhir. The module of NWC is Fiqh of waqf, The strategy of collecting waqf funds, Waqf Management, The Strategy of distributing results and Benefits of waqf, Waqf risk management, Legal entity about waqf in Indonesia Research on waqf (U. of D. Gontor, 2018).

Especially in the potency enhancement of nazhir waqf, ICAST did the cooperation with Yayasan Pemeliharaan dan Perluasan Wakaf Pondok Modern (YPPWPM). Yayasan Pemeliharaan dan Perluasan Wakaf Pondok Modern (YPPWPM) is an institution engaged in fundraising, maintenance, expansion, and development of Pondok Waqf. In 2013, Pondok Modern has 1025 ha of waqf land and various productive economic efforts to support the independence of the Pondok. The Chairperson of the waqf development institution is $\mathrm{K} . \mathrm{H}$. Imam Shobari, S.Ag (Gontor, 2013).

The tasks of YPPWPM are divided into three: first is the maintenance and agriculture division with the tasks of maintaining the land, agriculture, and results of economic activities. The second is the expansion and equipment division in handling waqf expanding and taking care of the legal status due to the administration of the land. The third division is related to building and equipment which is responsible for maintaining and adding building with its equipment for educational and teaching purposes (Cahyo \& Muqorobin, 2019).

YPPWPM has various programs to enhance and enlarge waqf potencies through waqf land and enterprises. In waqf land, YPPWPM used two ways: ijarah and musharakah contract, in which the renting price and the profit sharing will be determined by the degree of land's fertility and the contribution level in the contract respectively (D. Gontor, Ahmad, Ramzi, Che, \& Ekonomi, 2013).

Waqf business is previously realized in many districts and waqf land develops year by year. Table 3 below shows, the data of the enlargement of waqf land from 2016 until 2018, that the land has reached 12.643.712 $\mathrm{m}^{2}$. (Cahyo \& Muqorobin, 2019):

\begin{tabular}{ccc}
\multicolumn{2}{c}{$\begin{array}{c}\text { Table } \mathbf{3} \\
\text { The Enlargement of Gontor Waqf Land } \\
\text { 2016-2018 }\end{array}$} \\
\hline No & Year & Large $\mathbf{~ m}^{\mathbf{2}}$ \\
\hline 1 & 2016 & 11.081 .968 \\
2 & 2017 & 12.620 .269 \\
3 & 2018 & 12.643 .712 \\
\hline
\end{tabular}

Source: YPPWPM

The waqf land of Pondok Modern Darussalam Gontor was spread in 24 regions throughout Indonesia, obtained from accepting of waqf land of purchasing a new waqf land. The waqf property of pondok in the form of facilities and infrastructure like the mosque, residential college, school buildings, and so on is spread throughout Gontor branches: 14 branches in Gontor for boys and 7 branches in Gontor for girls (P. M. D. Gontor, n.d.).

Nazhir waqf has to enhance Islamic business or waqf investment through waqf assets. ICAST collaborated with YPPWPM do some experimental studies in waqf investment by establishing various business units in pondok that could enhance nazhir potency, such as rice mill, printing, shops, material for building a shop, book store, photocopy shop, Family Welfare Cooperation, chemists, drug store, ice factory, grocery store, transportation, canteen, inn, chicken butcher, bakery, beverage, sports shop, convection, magazine, palm oil garden, rice field, clove farming, husbandry, etc. All of these works are carried out by students and teachers, while the revenue will be spent for the needs of the institution and some will be distributed for teachers and students' welfare (Bahroni, 2016).

\section{Seminar and Workshop}

Waqf is one of the Islamic Economics pillars that has not been much discussed by Islamic economists, practitioners, or even government. Actually, waqf is a potential source of funding that could continue to provide socioeconomic benefits to the society perpetually. Therefore, education and dissemination of waqf to the community in the form of seminars, workshops, public lectures, and Tabligh Akbar is a must. The education of endowments by focusing on the Figh of Waqf to the general public has been carried 
out by running a campaign and educational movement called GISWAF (Indonesian Awareness of Waqf Movement). GISWAF is carried out by doing the National Waqf Roadshow to various provinces and Regencies/ Cities so that a Waqf Awareness Community arises. The education of endowments is also carried out through Tabligh Akbar and Waqf Seminar to Mosque manager and Educational Foundation, as well as the Waqf Training to the general public, specifically the waqf practitioner (U. of D. Gontor, 2018).

In the disseminating of waqf spirits, ICAST held three-level courses: basic level, intermediate level, and advanced level. The basic level is the introduction of figh and awqaf management and the history of waqf civilization with a duration of 6 hours. The intermediate level course consists of management of awqaf for poverty alleviation with the concept of waqf and its importance, the Sharia principles governing awqaf, the socio-economic impact of awqaf on poverty alleviation, the developmental aspects of Awqaf, and social justice of implementing awqaf by looking at a number of case studies; the course is held for 12 hours. The third is advanced level course consists of risk management in awqaf institutions, the main concepts and tools of waqf management, the various models of waqf, and the various methods of risk management in waqf; the duration of the course is 12 hours ( $U$. of $D$. Gontor, 2018).

\section{Analysis}

To reach the goals of all programs, institution should have tactics for influencing those programs. There are three Influencing tactics: The Head, The Heart, and The Hands as the ways/techniques of influencing waqf understanding to nazhir waqf in particular, and to all Muslim in general.

According to the head tactic, ICAST Indonesia with a Master in Waqf Economy program enhances a thinking development, critical thinking, literature, and concepts in disseminating waqf understanding. There are modules of program study which is divided into two modules: core and elective modules. A core module is the main course for a master student to find out about waqf understanding from Islamic jurisprudence, Islamic scholars in the past and contemporer, concepts of waqf productive to sustain Islamic civilization through education, health, welfare and so on; while elective modules are courses that complete and support the main core of a study. Although the program requires two years for all modules, it will make the students have qualified ability of figh waqf which is important because at this time many nazhir waqf do not understand about fiqh waqf from jumhur madzhab. The program is divided into thinking programs and experimental programs. The thinking program is held in the class where a lecturer gives a lesson by discussion. An experimental lesson is a class where every student can visit and observe waqf-based business units and do the interview with the caretakers of the units to discover the advantages and disadvantages of those units.

According to heart tactic, ICAST has done various program such as seminar that attracted many participants or wide element of society such Imam of masjid, lecturer, waqf activist, etc.; and also a workshop for the limited scope of participants with the aim to get the trainers and participants close to each other or do heart to heart that can make the program more interesting and create enthusiasm. Another agenda of ICAST in collaboration with YPPWPM and Indonesian Central Bank is a forum group discussion between headmasters of Islamic boarding schools, Islamic institutions, ZISWAF institutions to share knowledge, concepts of business, and the development of several education institutions based on waqf productive. Those agendas before have many benefits to make waqf understanding disseminated widely when the definition of waqf is not only in the head but embedded in deep of heart of headmasters and waqf practitioners.

From hand tactic, ICAST does a collaborating event and program with many institutions such as Indonesian Waqf Board (BWI) and Indonesian Central Bank (BI) in Islamic Economics Festival held in several cities like Surabaya, Jakarta, and Kalimantan Province. There is also a collaboration seminar namely Gerakan Indonesia Sadar Wakaf (GISWAF) or the movement of waqf awareness for Indonesia with the main goals to accelerate the waqf ecosystem between activists of waqf in Indonesia. Moreover, waqf dissemination agenda through online has a wider impact than the offline agenda. Those agenda spread through social media such as Instagram, Whatsapp group, website, Youtube by providing online education, teaching, question and answer, and quotes and examples from waqf consumptive or productive in the past and present. 


\section{Conclusions}

The conclusion of this research is that the influence of waqf understanding is done through International Center for Awqaf Studies carried out by holding four programs: Master in Waqf Economy, Research and Publication, Nazhir Waqf Certification, and Workshop and Seminar.

The strategy of ICAST UNIDA Gontor in influencing waqf is by applying three approaches known as the head, the heart, and the hand tactic. The head tactic consists of a compilation of courses, seminar, postgraduate program on waqf literature with the main module, and elective module of the center. Second, the heart tactic is a program to bound participants or practitioners of waqf with trainer through workshop, discussion, and lecture. Third, the hand tactic is a collaboration between ICAST UNIDA Gontor and several agencies, institutions of waqf, universities, and Indonesian Central Bank to enhance nazhir competency in waqf development.

\section{References}

3412-1565077565-190723_IPP_TingkatKemiskinan-di-Indonesia-Menurun_OP2. (n.d.).

Alhamuddin, A. (2018). Abd Shamad alPalimbani's Concept of Islamic Education: Analysis on Kitab Hidayah al-Sālikin fi Suluk Māsālāk lil Muttāqin. QIJIS (Qudus International Journal of Islamic Studies), 6(1), 89-102.

America, C., Michigan, O., East, A., Creek, B., Officer, C. I., \& Secretary, C. (2010). International Encyclopedia of Civil Society. In International Encyclopedia of Civil Society (pp. 1630-1633). Retrieved from https://doi.org/10.1007/978-0-38793996-4

Anwar Bashori, M., Ekonomi, D., \& Syariah, D. K. (2018). INDONESIA X 7 TH QUARTERLY CONFERENCE.

Arikunto, S. (1998). Prosedur Penelitian Suatu Pendekatan Praktek. Jakarta: Rineka Cipta.

Bahroni, I. (2016). Streamlining Education System Through Waqf Enlargement. At Ta'Dib, 11(1), 1-21. Retrieved from https://doi.org/10.21111/at-tadib. v11i1.620

Cahyo, E. N., \& Muqorobin, A. (2019). Strategi Pengembangan Wakaf Berkelanjutan Sektor Pertanian Pada
Yayasan Pemeliharaan dan Perluasan Wakaf Pondok Modern (YPPWPM) Gontor Ponorogo. Falah: Jurnal Ekonomi Syariah, 4(2), 35. Retrieved from https://doi. org/10.22219/jes.v4i2.9872

Dellaert, M., \& Davydov, S. (2017). Influencing: The Skill of Persuasion Building Commitment and Getting Results. Centre for Creative Leadership, 1-16.

Ekonomi, F., \& Iqtishodia, T. R. (2018). Optimalisasi Pengelolaan Wakaf di Indonesia, 18. Retrieved from https:// fem.ipb.ac.id/d/iqtishodia/2018/ Iqtishodia_20180125.pdf

Fisher, E. J., \& Santana Gonzalez, Y. (2013). The Art of Influencing and Persuasion: How Managers Can Put 'Square Pegs' into 'Round Holes'. Journal of Management Research, 5(4), 1. Retrieved from https:// doi.org/10.5296/jmr.v5i4.3971

Gabriel, D. (n.d.). Inductive and Deductive Approaches to Research. Retrieved 22 November 2019, from https:// deborahgabriel.com/2013/03/17/ inductive-and-deductive-approaches-toresearch/

Gontor. (2013). YPPWPM. Retrieved 30 April 2020, from https://www.gontor.ac.id/ lembaga/yppwpm

Gontor, D., Ahmad, S., Ramzi, M., Che, H., \& Ekonomi, F. (2013). Wakaf Produktif dalam Pembangunan Pendidikan : Kajian di Pondok Moden Darussalam Gontor , Indonesia Waqf Productive in Development Education : A Case Study at Pondok Modern. In Persidangan Kebangsaan Ekonomi Malaysia Ke 8 (Vol. 3, pp. 1302-1314).

Gontor, P. M. D. (n.d.). Warta Dunia Pondok Modern Darussalam Gontor Ponorogo. Darussalam Press, Vol. 71.

Gontor, U. of D. (2018). ICAST Profile. Ponorogo: University of Darussalam Gontor.

Hadi, S. (1981). Metodologi Penelitian Research I. Yogyakarta: Yayasan Penelitian Fakultas Psikologi UGM.

Hall, A., \& Barrett, L. (2007). Influence : The essence of leadership. NebGuide. Retrieved from https://doi.org/G1695

Hendra, Y. (2019). Existence and Nazhir Accountability of Waqf in Bengkalis District, 8(08), 5-18.

ICAST. (2018). ICAST International Center for Awqaf Studies. Retrieved 18 November 2019, from http://icast.unida.gontor. ac.id/

Kahf, M. (1998). of AWQAF PROPERTY, 1-45. Kahf, M. (2016). Waqf: a Quick Overview, 
2. Retrieved from http://monzer.kahf. com/papers/english/WAQF_A_QUICK_ OVERVIEW.pdf

Kerjasama Bank Indonesia dan Universitas Darussalam Gontor - Bank Sentral Republik Indonesia. (n.d.). Retrieved 12 June 2020, from https://www.bi.go. id/id/institute/kegiatan/kuliah-umum/ Pages/Kerjasama-Bank-Indonesia-danUniversitas-Darussalam-Gontor.aspx

Pena, T. P. (n.d.). Kamus Besar Bahasa Indonesia. Gitamedia Press.

Potensi dan Kontribusi Wakaf di Indonesia - ISEFID. (n.d.). Retrieved 12 June 2020, from https://isefid.id/potensi-dankontribusi-wakaf-di-indonesia/

Purwanto, Y. (2004). Nā ir Al-Waqf in Imam Syafi ' $\mathrm{i}$ ' $\mathrm{S}$ View and Its Implementation in Indonesia, 04(01), 49-62.

Sugiyono. (2014). Memahami Penelitian Kualitatif. Bandung: Alfabeta.

Syariah, D. E. dan K. B. I., \& Airlangga, D. E. S. F. E. dan B. U. (2016). Wakaf:
Pengaturan dan Tata Kelola yang Efektif. Seri Ekonomi dan Keuangan Syariah.

Umam, K. (2014). Developing Management Standards Based on Islamic Values: Case Study of Darussalam Gontor Modern Islamic Boarding School. Qudus International Journal of Islamic Studies, $1(2), 145-162$. Retrieved from https:// doi.org/10.21043/QIJIS.V1I2.183

Utsman, S. (2014). Metodologi Penelitian Hukum Progresif. Yogyakarta: Pustaka Pelajar.

Wakaf Kekinian Masuk Kurikulum Pendidikan Makassarinside.com. (n.d.). Retrieved 12 June 2020, from https://makassarinside. com/wakaf-kekinian-masuk-kurikulumpendidikan/

Yumarni, A., Suhartini, E., \& Mulyadi. (2019). Mandatory sector in appointment legal entity of Nazhir in waqf regulation and foundation regulation in Indonesia. International Journal of Scientific and Technology Research, 8(11), 1244-1246. 